\title{
Reduction of Iraqi Sand to Produce Silicon with High Purity
}

\author{
Sami I. J. Al-rubaiey, Zahraa M. Abd Ali \\ Department of Production Engineering \& Metallurgy, University of Technology \\ drengsami@yahoo.com
}

\begin{abstract}
This study deals with extraction of silicon from Iraqi sand. The sand was supplied by State Company for Mining Industries from Um-Erdhuma Formation in Anbar Province. It is found that Iraqi sand has $98 \%$ of silica $\left(\mathrm{SiO}_{2}\right)$.Pyrometallurgy and hydrometallurgy processes were applied for extraction of silicon by reduction and leaching respectively. Reduction was carried out in an alumina crucible by using magnesium powder with particle size of $75 \mu \mathrm{m}$ as reducing agent under argon gas. Several parameters were studied to determine the best results that affected the extraction of silicon. These parameters involved the reduction temperatures $(750,850,950){ }^{\circ} \mathrm{C}$ and ratio of $\mathrm{Mg} / \mathrm{SiO}_{2}$ (2:1, 2.5:1, 3:1). The best conditions for the reduction of Iraqi sand to produce silicon were, at $850{ }^{\circ} \mathrm{C}, 2: 1 \mathrm{Mg} / \mathrm{SiO}_{2}$ with $99.3 \%$ purity and at $950{ }^{\circ} \mathrm{C}, 3: 1 \mathrm{Mg} / \mathrm{SiO}_{2}$ with $99.2 \%$ purity. Leaching processes were done for purification of produced silicon by using $4: 1$ volume ratio of $4 \mathrm{M} \mathrm{HCl}$ and $4 \mathrm{M} \mathrm{CH} 3 \mathrm{COOH}$ respectively for one hour at $70{ }^{\circ} \mathrm{C}$. Additional purification step was done by using $\mathrm{H}_{2} \mathrm{SO}_{4}$ acid, which was diluted by $1: 4$ ratio for three hours at $100^{\circ} \mathrm{C}$.
\end{abstract}

Keywords: Iraqi sand, magnesiothermic reduction, silicon, acid leaching.

Paper History :(Received:28-1-2019;Accepted:26-62019)

\section{1-Introduction}

The Iraqi sand is characterized by a high percentage of $\mathrm{SiO}_{2}$ and other elements exist in [1]. The synthesis of high purity silicon from natural substances has been performed by several researchers, using metals like $\mathrm{Mg}$, $\mathrm{Ca}, \mathrm{Al}$ or $\mathrm{C}$ as reducing agents [6][7]. jehad \&jasim[2]study the extraction of silicon with high purity of $99 \%$ by using Iraqi starting materials

(Quartzite rock, plant coal) in electric arc furnace at $1500{ }^{\circ} \mathrm{C}$. Mishra et al. [3] produced Polycrystalline silicon from amorphous silica obtained from rice-husk white ash by using calcium, the reduction temperature $720^{\circ} \mathrm{C}$. The final purity of silicon was $99.9 \%$ after acid leaching with concentrated HNO3 and HF. Sadique [4] extracted high purity silicon $(99.1 \%$ purity) from waste of silica fume (SF). He reached to $99.1 \%$ Si by using Pyrometallurgical process .The best temperature for reduction were (750850) ${ }^{\circ} \mathrm{C}$ at $2: 1$ mixing ratio of $\mathrm{Mg} / \mathrm{SF}$. Al Mubarok et al.[5] produced Silicon from high purity silica obtained from Lapindo mud. It was found that the
Pyrometallurgical process at $650{ }^{\circ} \mathrm{C}$ for 3 hours get high purity of silicon $(98 \%)$ when the ratio of $\mathrm{Mg} / \mathrm{SiO}_{2}$ was 5/6.2. The product was treated with $\mathrm{HCl}$ : $\mathrm{CH} 3 \mathrm{COOH}$ solutions followed with $\mathrm{HF}: \mathrm{CH} 3 \mathrm{COOH}$ solutions. Reduction by magnesium is more suitable due to [8]:

(a) Its simplicity and low temperature conditions.

(b)The supply of reasonably pure magnesium is assured, since it is the eighth most abundant material in the Earth's crust.

(c)Reaction products other than silicon can easily be removed by acid leaching.

The aim of this work is to produce high purity silicon from Iraqi sand by using Pyrometallurgy and hydrometallurgy processes.

\section{2-Materials and methods}

2-1The silica sand sample was supplied by state company for mining industry from Um-Erdhuma Formation in Anbar Province / Western Iraq. The chemical analysis of the elements was carried out by using X-ray fluorescence-XRF as shown on Table (1).

2-2Magnesium powder the powder of $\mathrm{Mg}$ was bought from Iraqi market (Thomas baker) with minimum assay $98.5 \%$ with particle size $75 \mathrm{um}$ is used as reducing agent.

2-3Mixing and pressing processes different ratios of $\mathrm{Mg} / \mathrm{SiO}_{2}(2: 1,2.5: 1,3: 1)$ were mixed for 1 minute manually. The specimens were poured into the compression die having a bore diameter of $3 \mathrm{~cm}$ in predetermined amounts and pressed under 20 tons for 1 minute.

Table (1): Chemical composition of the silica sand.

\begin{tabular}{|l|l|}
\hline $\mathrm{SiO} 2$ & $98 \%$ \\
\hline $\mathrm{Al} 2 \mathrm{O} 3$ & 0.6 \\
\hline $\mathrm{Fe} 2 \mathrm{O} 3$ & 0.05 \\
\hline $\mathrm{SO} 3$ & 0.04 \\
\hline $\mathrm{TiO} 2$ & 0.09 \\
\hline $\mathrm{CaO}$ & 0.3 \\
\hline $\mathrm{P} 2 \mathrm{O} 5$ & 0.6 \\
\hline
\end{tabular}

2-4 Reduction Process the reduction process was carried out in Carbolite furnace (type CWF12/13, England, max. 
temp $1200^{\circ} \mathrm{C}$ ) under inert gas argon with different temperatures $(750,850,950)^{\circ} \mathrm{C}$ for 2 hours. The specimen put in steel crucible ( $11 \mathrm{~cm}$ diameter, $15 \mathrm{~cm}$ length) which covers tightly. The cover was open from the middle to insert the tube of steel for argon gas flow. After that the products were taken for XRD analysis.

2-5 Leaching Processes the leaching processes were done to remove impurities in the reduction product. The first leaching step was done by using $4 \mathrm{M} \mathrm{HCl}$ and $25 \%$ $\mathrm{CH} 3 \mathrm{COOH}$ at $70{ }^{\circ} \mathrm{C}$ for 1 hour using magnetic stirrer. The insoluble residue separated from solution by vacuum pump using filter paper. After completion of the filtration, the filter cake was washed with distilled water for several times and then dried in an electric drying Oven at $100{ }^{\circ} \mathrm{C}$ for two hour. The filtrate $\left(\mathrm{MgCl}_{2}\right)$ can be used as liquid for its benefits or can be recycled to recover magnesium again. Additional purification step was done with $\mathrm{H} 2 \mathrm{SO} 4$ for $3 \mathrm{~h}$ at $100{ }^{\circ} \mathrm{C}$, acid dilution ratio 1:4.

\section{2-6 X-ray diffraction analysis}

It was done for the identification of the compounds of the reduction product was made by X-ray diffraction (XRD) analysis type (BRUKER), voltage $30 \mathrm{kv}$, current 10MA, $\chi \mathrm{Cu} 1.540 \mathrm{~A}^{\circ}$, Scan rate (speed) $5-10^{\circ} \mathrm{Min}$. The test was done at Geological Department, College of Sciences, University of Baghdad.
The purity of silicon powder was carried out by using X-ray fluorescence-XRF (AMETEK 2010, Germany). The analysis was conducted at Geological Department, College of Sciences, University of Baghdad.

\section{3- Results and discussion}

\section{3-1 Reduction Reaction}

The reduction reaction was carried out in closed steel crucible. Atypical product is shown in Fig (1) and The corresponding X-ray diffractogram in Fig (2) . There are several compounds appear in the reduction products, at $(750,850)^{\circ} \mathrm{C}$ the product have following compounds: silicon, $\mathrm{MgO}$ and $\mathrm{Mg}_{2} \mathrm{Si}$ whereas at $950^{\circ} \mathrm{C}$ are silicon , $\mathrm{MgO}$ and $\mathrm{MgSiO}_{3}$. The sharp and high intensity of $\mathrm{MgO}$ and $\mathrm{Si}$ peaks indicate that those two are the major phases under the experimental conditions. The following solid/gas reactions might have occurred [9]:

$$
\begin{aligned}
& \mathrm{SiO}_{2}(\mathrm{~s})+4 \mathrm{Mg}(\mathrm{g})=2 \mathrm{MgO}(\mathrm{s})+\mathrm{Mg}_{2} \mathrm{Si}(\mathrm{s}) \\
& \mathrm{Mg}_{2} \mathrm{Si}(\mathrm{s})+\mathrm{SiO}_{2}(\mathrm{~s})=2 \mathrm{MgO}(\mathrm{s})+2 \mathrm{Si}(\mathrm{s})
\end{aligned}
$$

Banerjee et al.[8] and Kondoh et al.[10] reported in Differential temperature analysis that onset temperature containing $\mathrm{Mg}$ and silica powder was approximately 493$540^{\circ} \mathrm{C}$ well below the melting point of $\mathrm{Mg}$. These results suggested that the reactions take place in solid state.

\section{2-7 X-Ray fluorescence analysis}

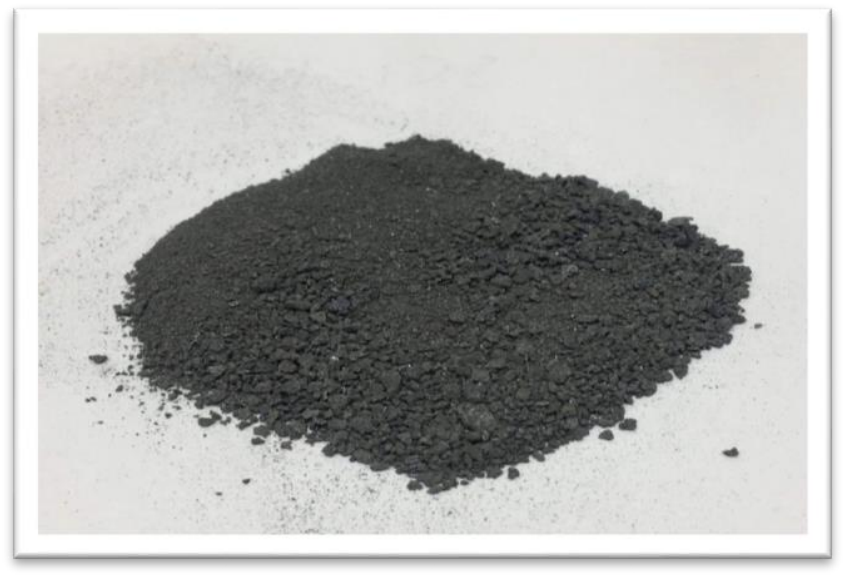

Figure (1) Example of reduced product

\section{3-2 Effect of Addition Magnesium Powder}

Table (2) shows the $\mathrm{Mg}$ powder added to silica in different ratios as 2:1, 2.5:1, 3:1. As seen from table (2) the amount of $\mathrm{Mg}$ addition have large effect on the reduction of silica. It had been shown that at $750{ }^{\circ} \mathrm{C}$ using ratio of $3: 1 \mathrm{Mg} / \mathrm{SiO}_{2}, \mathrm{Mg} 2 \mathrm{Si}$ appears with very high amount $(26 \%)$, whereas at 2:1 ratio, appears with small amount $(12.7 \%)$. At $850{ }^{\circ} \mathrm{C}$ when the ratio is $3: 1$ $\mathrm{Mg} / \mathrm{SiO}_{2}$ the amount of $\mathrm{Mg} 2 \mathrm{Si}$ is $(9 \%)$ whereas at $2: 1$ $\mathrm{Mg} / \mathrm{SiO}_{2}$ decrease to about $(0.1 \%)$. As a result of XRD the intensity of Si peaks increases as the ratio decreases to about 2:1 . Kalem [9] explain that by increasing $\mathrm{Mg}$ 
content in the batch excess $\mathrm{Mg}$ reacts with $\mathrm{Si}$ to produce $\mathrm{Mg} 2 \mathrm{Si}$ according to following equation.

$\mathrm{Si}(\mathrm{s})+2 \mathrm{Mg}(\mathrm{g})=\mathrm{Mg} 2 \mathrm{Si}(\mathrm{s})$

Dvorina at el. [11] found that $\mathrm{Mg} 2 \mathrm{Si}$ causes violent reactions upon contact with $\mathrm{HCl}$. So the product of $\mathrm{Mg} 2 \mathrm{Si}$ at high amount is undesirable because it react to form silane gas $\left(\mathrm{SiH}_{4}\right)$ which cause losses in $\mathrm{Si}$ element. The
$\mathrm{MgSiO}_{3}$ compound appears with minimum amount (4.2 $\%)$ at $3: 1$ ratio while it is increased to about $(6.5 \%)$ at $2: 1$ ratio.

Figure (3) and (4) show the relationship between formations of $\mathrm{Mg} 2 \mathrm{Si}$ and $\mathrm{MgSiO} 3$ with $\mathrm{Mg} / \mathrm{SiO}_{2}$ ratios, Indicates that at ratio of 2:1 produced $\mathrm{Mg} 2 \mathrm{Si}$ with least amount and 3:1 ratio produced $\mathrm{MgSiO}_{3}$ with least amount.

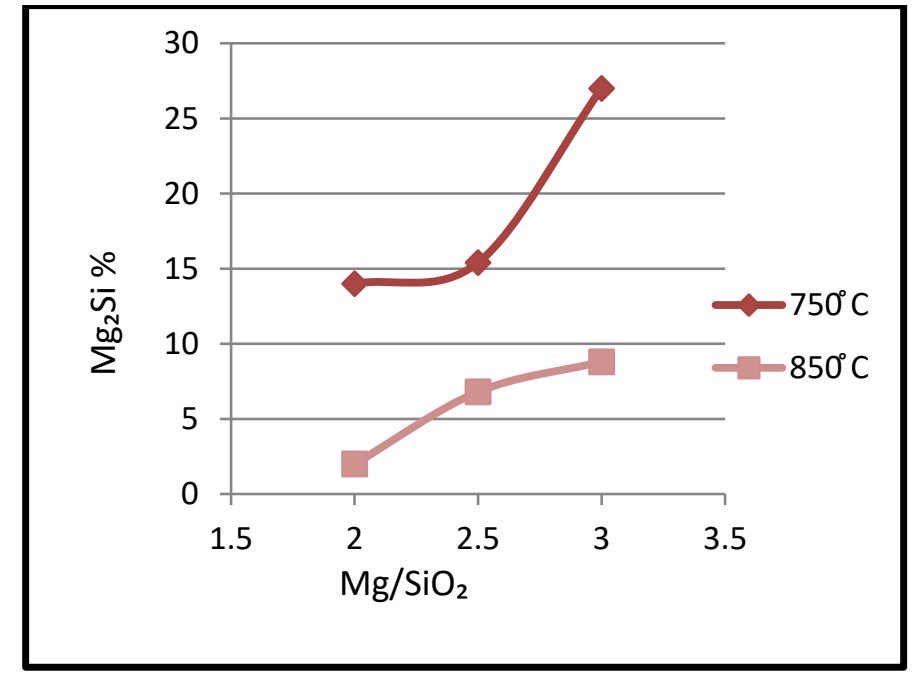

Figure (3) effect of $\mathrm{Mg} / \mathrm{SiO}_{2}$ ratio on $\mathrm{Mg} 2 \mathrm{Si}$.

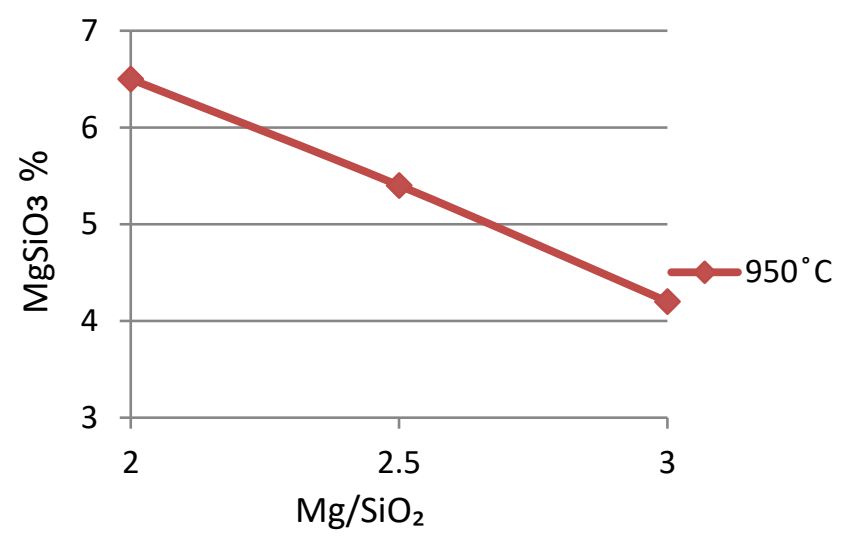

Figure (4) effect of $\mathrm{Mg} / \mathrm{SiO} 2$ ratio on $\mathrm{MgSiO3}$.

\section{3-3 Effect of Temperatures}

Table (2) shows the effect of reduction temperature on the reduction reaction of $\mathrm{SiO}_{2}$ at constant ratio of $\mathrm{Mg} / \mathrm{SiO}_{2}$. According to XRD at higher temperatures of $850^{\circ} \mathrm{C}$ and $950^{\circ} \mathrm{C}$, peak of $\mathrm{Mg} 2 \mathrm{Si}$ decreased. Sadique [4] explain that at high temperature $\mathrm{Mg} 2 \mathrm{Si}$ content will decrease. However, at temperature of $950^{\circ} \mathrm{C} \mathrm{MgSiO}_{3}$ produced. Banerjee at el. [8] explained that When temperature increase the formation of $\mathrm{MgSiO}_{3}$ increase according to reaction (4). Figure (5) represents the effect of temperature on $\mathrm{Mg} 2 \mathrm{Si}$ compound at different ratios. As described previously, the formation of $\mathrm{Mg} 2 \mathrm{Si}$ at $750^{\circ} \mathrm{C}$ significantly increased at higher $\mathrm{Mg} / \mathrm{SiO}_{2}$ ratio. Comparing the results of $750^{\circ} \mathrm{C}$ with that of $850^{\circ} \mathrm{C}$ and $950^{\circ} \mathrm{C}$ (Table2). At 3:1 ratio of $\mathrm{Mg} / \mathrm{SiO}_{2}$ the amount of $\mathrm{Mg} 2 \mathrm{Si}$ decreased from $26 \%$ at $750^{\circ} \mathrm{C}$ to $0 \%$ at $950^{\circ} \mathrm{C}$. While at 2.5:1 ratio of $\mathrm{Mg} / \mathrm{SiO}_{2}$ the amount of $\mathrm{Mg} 2 \mathrm{Si}$ decreased from $17 \%$ at $750^{\circ} \mathrm{C}$ to $4 \%$ at $850^{\circ} \mathrm{C}$. 


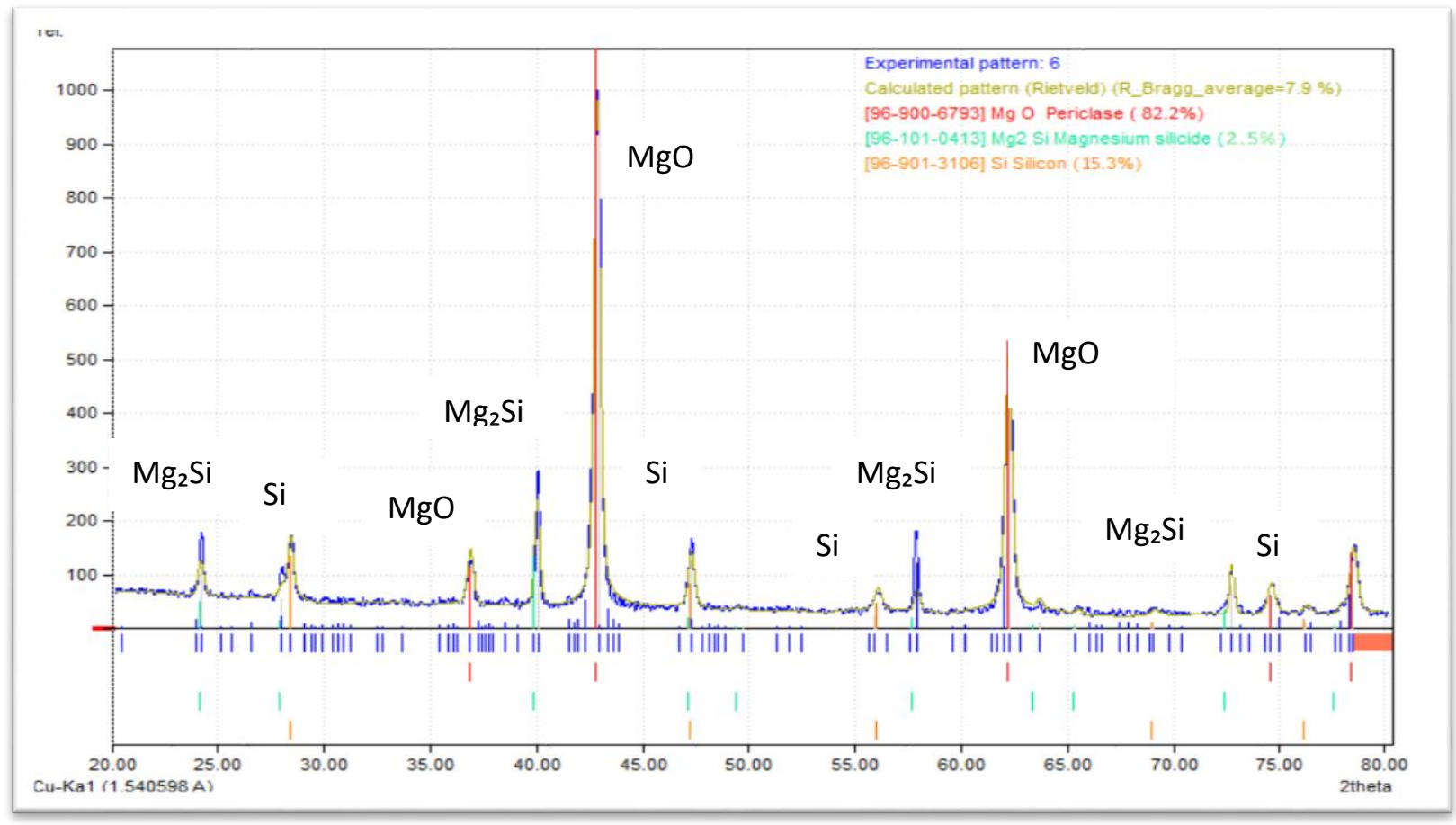

Figure (2) XRD pattern of reduction products at $850^{\circ} \mathrm{C}$ and ratio of $\mathrm{Mg} / \mathrm{SiO}_{2}=2: 1$.

Table (2) quantification of XRD for experimental variables for reduction.

\begin{tabular}{|c|c|c|c|c|c|c|}
\hline $\mathrm{Mg} / \mathrm{SiO}_{2}$ & $\mathrm{Temp}^{\circ}, \mathrm{C}$ & $\begin{array}{c}\mathrm{Si} \% \\
\text { average }\end{array}$ & $\mathrm{MgO} \%$ & $\mathrm{SiO}_{2} \%$ & $\mathrm{Mg}_{2} \mathrm{Si} \%$ & $\mathrm{MgSiO}$ \\
\hline \multirow{3}{*}{$2: 1$} & 750 & 9.6 & 72.3 & 5.2 & 12.7 & - \\
\cline { 2 - 7 } & 850 & 16.2 & 79.7 & 4.9 & 0.1 & - \\
\cline { 2 - 7 } & 950 & 14.9 & 74.8 & 3.6 & - & 6.5 \\
\hline \multirow{3}{*}{$2.5: 1$} & 750 & 6.4 & 75.9 & 0.6 & 17 & - \\
\cline { 2 - 7 } & 850 & 15.8 & 75.8 & 3.4 & 4.9 & - \\
\cline { 2 - 7 } & 950 & 15.3 & 77.4 & 0.7 & - & 5.4 \\
\hline \multirow{3}{*}{$3: 1$} & 750 & 6 & 65.8 & 1.1 & 26.9 & - \\
\cline { 2 - 7 } & 850 & 13.1 & 75.8 & 2.1 & 8.8 & - \\
\cline { 2 - 7 } & 950 & 16.3 & 78.3 & 1.1 & - & 4.2 \\
\hline
\end{tabular}

\section{3-4 Evaluation of Silicon Amount Production}

The silicon was evaluated, since the main purpose of the reduction experiments is to achieve the highest amount of Si with high purity. Figures (6) and (7) show Si average as a function of $\mathrm{Mg} / \mathrm{SiO}_{2}$ ratio and temperature respectively. As seen, the maximum amount of $\mathrm{Si}$ is achieved at $\mathrm{Mg} / \mathrm{SiO}_{2}$ ratio of $2: 1$ at $850{ }^{\circ} \mathrm{C}$ because the less amount of $\mathrm{Mg} 2 \mathrm{Si}$ was produced .As well at $\mathrm{Mg} / \mathrm{SiO}_{2}$ ratio of $3: 1$ at $950{ }^{\circ} \mathrm{C}$ because the less amount of $\mathrm{MgSiO} 3$ was produced. 


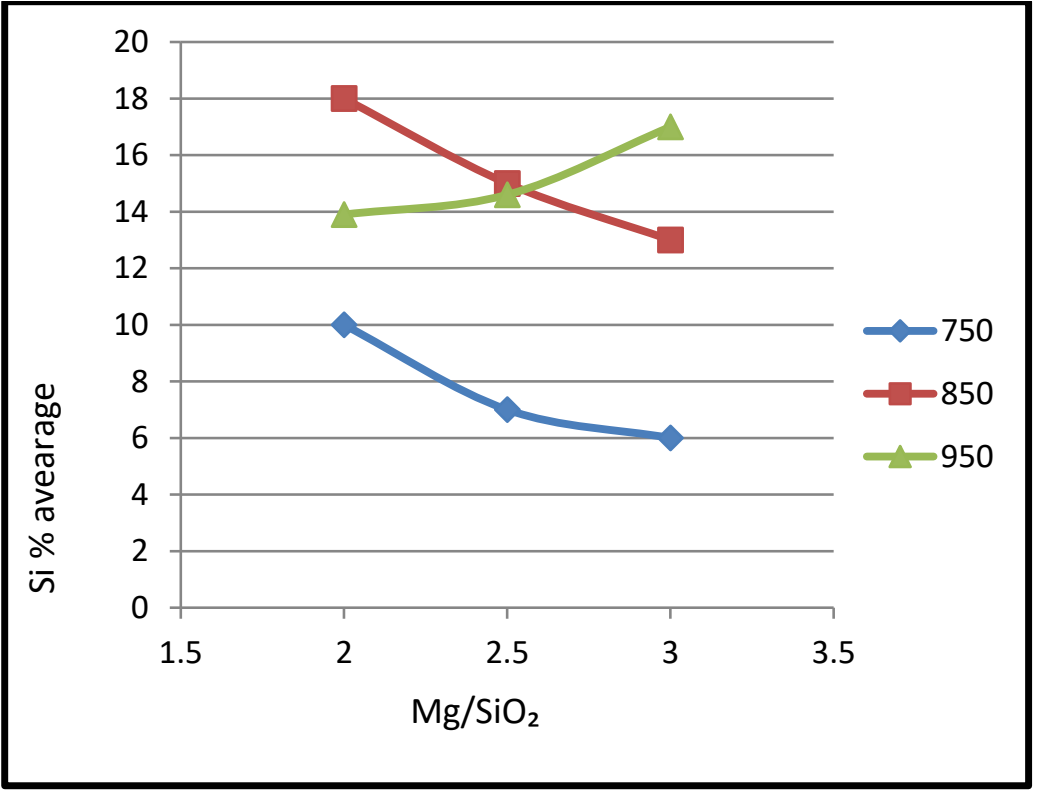

Figure (6) Effect of $\mathrm{Mg} / \mathrm{SiO}_{2}$ ratio on silicon average with different temperatures.

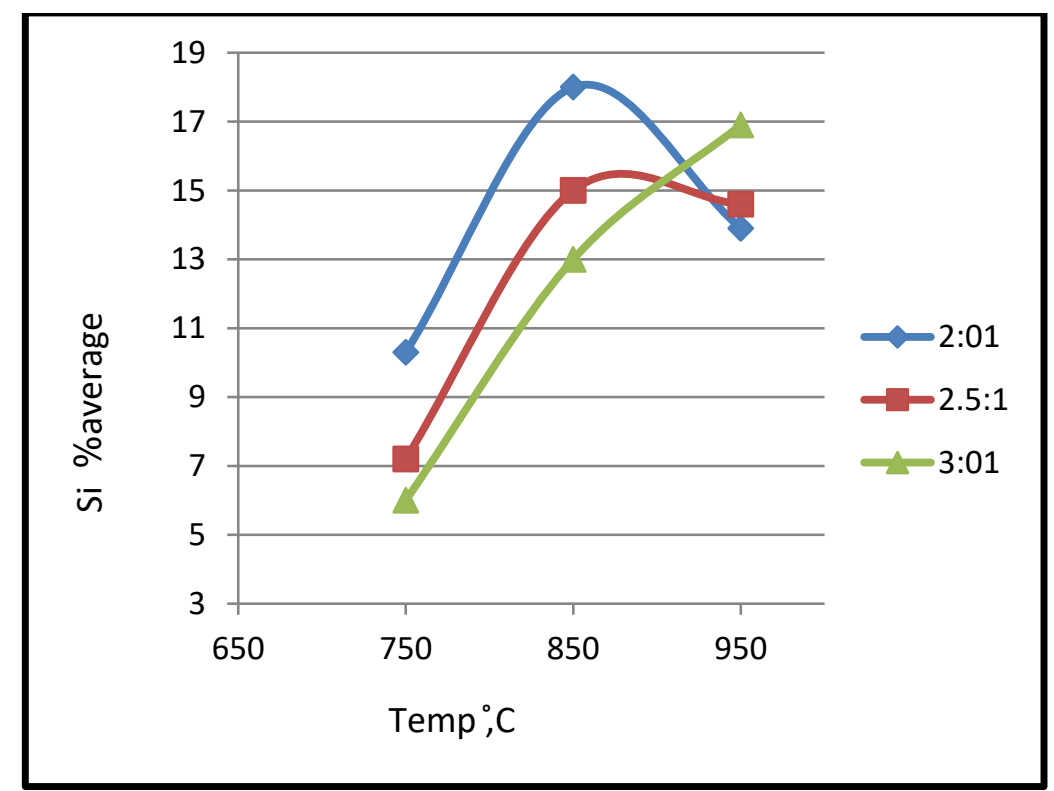

Figure (7) effect of temperatures on silicon average with different $\mathrm{Mg} / \mathrm{SiO}_{2}$ ratio.

\section{3-5 Leaching of Mg Compounds}

The leaching process of $\mathrm{MgO}, \mathrm{MgSiO}_{3}$ and $\mathrm{Mg}_{2} \mathrm{Si}$ was done by treatment with $4 \mathrm{MHCl}$ and $25 \%$ acetic acid solutions at $70{ }^{\circ} \mathrm{C}$ for 1 hour. Nandi et.al [12] proved that Magnesium silicide $\left(\mathrm{Mg}_{2} \mathrm{Si}\right)$ reacts with $\mathrm{HCl}$ solution and produces silane gas as shown in equation (5). Raschman [13] had been proved that $\mathrm{MgO}$ is readily dissolved in $\mathrm{HCl}$ and remains in the solution as $\mathrm{MgCl} 2$ as shown in equation (6). From figure (8) found that $\mathrm{MgO}$ and $\mathrm{Mg}_{2} \mathrm{Si}$ peaks were not observed these results proved that the complete dissolution of $\mathrm{Mg}$ compounds.

$$
\begin{aligned}
& \mathrm{Mg}_{2} \mathrm{Si}(\mathrm{s})+4 \mathrm{HCl}(\mathrm{aq})=\mathrm{SiH}_{4}(\mathrm{~g})+2 \mathrm{MgCl}_{2}(\mathrm{aq}) \\
& \mathrm{Mg}^{2+}(\mathrm{aq})+2 \mathrm{Cl}^{-}=\mathrm{MgCl} 2(\mathrm{aq}) \\
& \operatorname{MgSiO} 3(\mathrm{~s})+\mathrm{HCl}(\mathrm{aq})=\mathrm{MgCl} 2(\mathrm{aq})+\mathrm{HSiO} 3(\mathrm{aq})
\end{aligned}
$$

Additional purification step was done with sulphuric acid. The leaching conditions were a leaching time of $3 \mathrm{~h}$, acid dilution ratio of $1: 4$, leaching temperature of about $100{ }^{\circ} \mathrm{C}$ and solid to liquid ratio of 1:6. The Chemical composition of pure silicon was done using the X-ray florescence spectrophotometer (XRF) table (3) and table (4). 
Table (3) Chemical Composition of pure silicon $\left(950^{\circ} \mathrm{C}, 3: 1\right)$.

\begin{tabular}{cc}
\hline $\mathrm{Si} \%$ & 99.21 \\
\hline $\mathrm{Al} 2 \mathrm{O} 3 \%$ & 0.718 \\
$\mathrm{Fe} 2 \mathrm{O} 3 \%$ & 0.065 \\
$\mathrm{CaO} \%$ & 0.001 \\
$\mathrm{SO} \%$ & 0.005 \\
\hline
\end{tabular}

Table (4) Chemical Composition of pure silicon $\left(850^{\circ} \mathrm{C}, 2: 1\right)$.

\begin{tabular}{cc}
\hline Si\% & 99.34 \\
\hline Al2O3\% & 0.591 \\
\hline Fe2O3\% & 0.051 \\
CaO\% & 0.003 \\
SO3\% & 0.015 \\
\hline
\end{tabular}

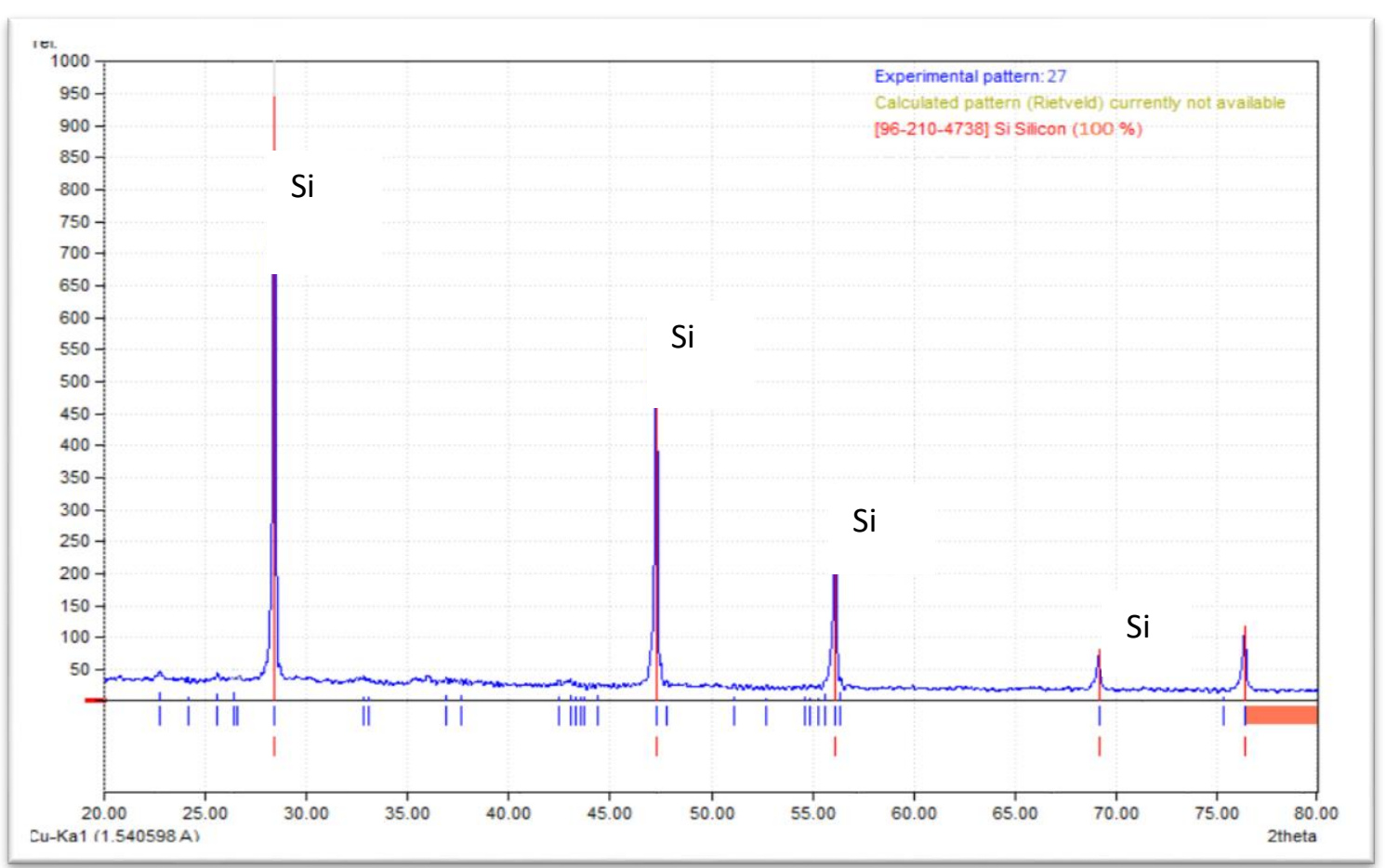

Figure (8) XRD pattern after initial leaching at $70^{\circ} \mathrm{C}$ for $1 \mathrm{hr}\left(\mathrm{Mg} / \mathrm{SiO}_{2}=3: 1\right.$ at $\left.950{ }^{\circ} \mathrm{C}\right)$. 


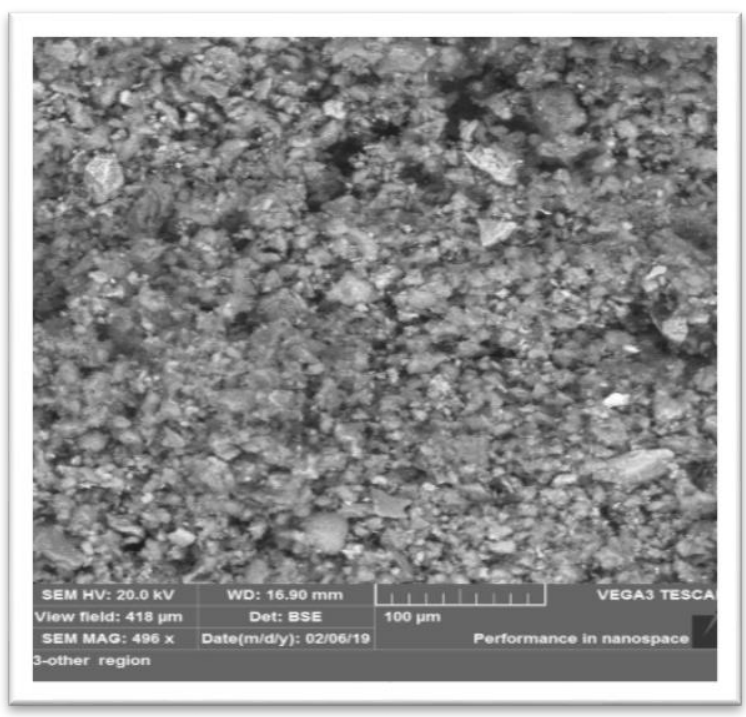

Figure (9) SEM of as produced silicon $(950,3: 1)$.

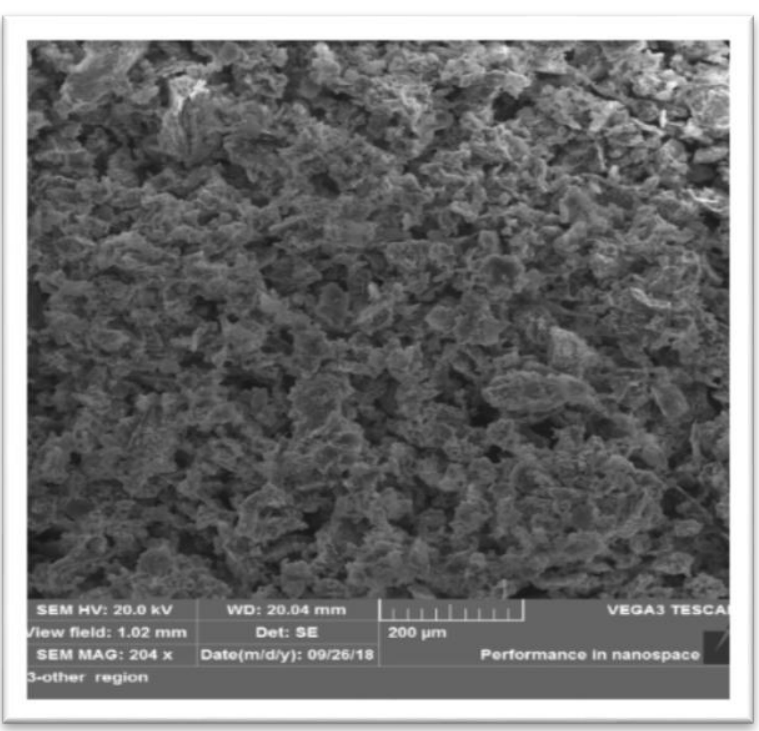

Figure (10) SEM of as produced silicon $(850,2: 1)$

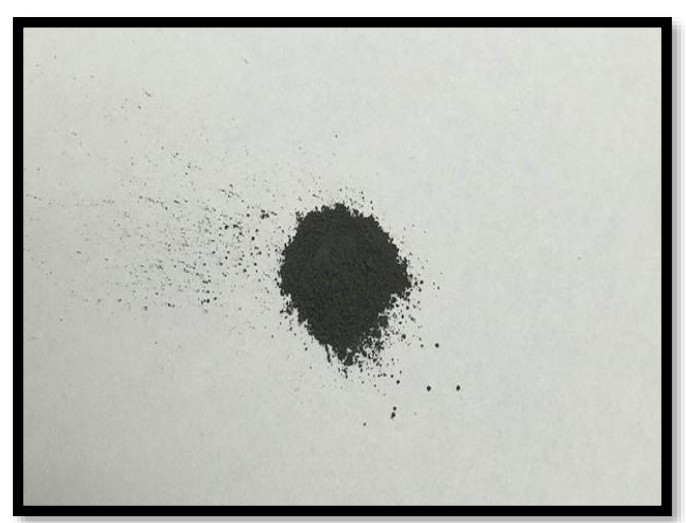

Figure (10) as produced silicon powder 
[3] Mishra P., Chakraverty A. and Banerjee H.D.; Production and purification of silicon by calcium reduction of rice-husk white ash, Materials Science, 20(1985),4387-4391.

[4] Sadique, S.E., Production and Purification of Silicon by Magnesiothermic Reduction of Silica Fume, MS.C.thesis, Dep. of M S. and Eng, University of Toronto, 2010

\section{4- Conclusions}

1- Pure Silicon has been successfully produced from Iraqi sand by using Pyrometallurgical and hydrometallurgical processes.

2- The reduction process was carried out with magnesium powder (75um particle size) as the reducing agent to decrease the reduction temperature of Iraqi sand.

3- The first leaching step $4 \mathrm{MHCl}, 25 \% \mathrm{CH} 3 \mathrm{COOH}$ carried out to remove $\mathrm{Mg}$ compounds.

4- Additional purification step was done with sulphuric acid to remove other impurities.

5- The best reduction conditions were found to be $2: 1,3: 1$ ratios of $\mathrm{Mg} / \mathrm{SiO}_{2}$ at $(850,950)^{\circ} \mathrm{C}$ with $99.3 \%$ and $99.2 \%$ purity respectively.

\section{Acknowledgment:}

This work was done in the laboratories of the Department of Production Engineering \& Metallurgy which is gratefully acknowledged.

\section{Reference:}

[1]Abass, A .A., Study the properties of the Iraqi sand for use in the pulp and through the carbon dioxide gas ,MS.C. Thesis, product Eng. University of technology, Baghdad, Iraq, 1978.

[2] J. Abed Taies \& J. H. Hassen, Production of Silicon Metal from Iraqi Sand, Baghdad for science, 11(2014).

[5] M. A. S. Al Mubarok, L. P. Setiawan, M. Utami and W. Trisunaryanti, Study of Acid Leaching in the Preparation of Silicon from Lapindo Mud ,Academic and Scientific Research 2(2014),31-36.

[6] I. Nazma and M. Akhter, X-Ray diffraction analysis of silicon prepared from rice husk ash, J. Mater. Sci. 23(1998).

[7] L. P. Hunt, J. P. Dismukes, J. A. Amick, A. Schei and K. Larsen, Rice hulls as a raw material for producing silicon, the Electrochemical Society, 131(1984), 16831686.
[8] H D.BANERJEE and S. SEN, Investigations on the Production of Silicon from Rice Husks by the Magnesium Method, Materials Science and Engineering, 52(1982), 173-179.

[9]. Kalem, T., Gas-solid dispIacement reactions for converting silica diatom frustules into $\mathrm{MgO}$ and $\mathrm{TiO} 2$, MS.C. thesis, Iowa State University 2004.

[10]. Kondoh K., Oginuma H., Yuasa E. and Aizawa T., Solid-state synthesis of $\mathrm{Mg} 2 \mathrm{Si}$ from $\mathrm{Mg}-\mathrm{Si}$ mixture powder. Mat. Trans., 42(2001), 1293-1300.

[11]. Dvorina L.A., Popova O.I., and Derenovskaya N.A., Sintered materials and components: preparation and some chemical properties of magnesium silicide. 77(1969) 2932.

[12] Nandi K.C., Mukherjee D., Biswas A.K. and Acharya H.N.; Optimization of acid concentration, temperature and particle size of magnesium silicide, obtained from rice husk, for the production of silanes. J. of Mat. Sci. Letters, 12 (1993) 1248-1250.

[13]. Raschman P.I., and Fedoročková A., Study of inhibiting effect of acid concentration on the dissolution rate of magnesium oxide during the leaching of deadburned magnesite, 71 (2004), 403-412.

[14].Larbi K.K., Synthesis of high-purity silicon from rice husks. MS.C. thesis, University of Toronto ,2010. 